\title{
REAL EXCHANGE RATE FLUCTUATIONS AND MONETARY SHOCKS: A REVISIT
}

\author{
SHIU-SHENG CHEN*,† \\ Department of Economics, University of Wisconsin-Madison, USA
}

\begin{abstract}
In this paper, I first estimate a structural VAR model by following Clarida and Gali (1994) and obtain results indicating that the variance of real exchange rates can be attributed more to monetary shocks when the sample span is extended. In order to further investigate this aspect, I then employ a VAR model with long-run US-UK annual data from 1889 to 1995. According to the variance decompositions, I find that monetary shocks can explain nearly $50 \%$ of real exchange rate variance in the long-run sample periods. All the evidence suggests that monetary shocks are indeed more important in a larger sample set. Copyright (C) 2003 John Wiley \& Sons, Ltd.
\end{abstract}

JEL CODE: F31; F41

KEY WORDS: Real exchange rate; monetary shocks

\section{INTRODUCTION}

There are a variety of reasons why researchers are interested in the impact of monetary shocks on real exchange rates. First, since exchange rate fluctuations are volatile and difficult to explain, many economists have long suspected that monetary shocks might play an important role in accounting for such behaviour. For example, Mussa (1986) argues that exchange rate fluctuations reflect sluggish price adjustment and increased volatility of monetary policy. Second, it is relevant to the recent literature on dynamic stochastic general equilibrium models of real exchange rates, which focuses on monetary shocks. For instance, see Obstfeld and Rogoff (1995), Beaudry and Devereux (1995), Chari et al. (2000).

Do monetary shocks matter in accounting for real exchange rate fluctuations? To answer this question, a number of empirical studies with different identifying assumptions have examined US data and obtained similar results. Clarida and Gali (1994) use the Blanchard-Quah identification strategy to estimate the share of exchange rate variability due to monetary shocks using quarterly US-Canada, US-Germany, US-Japan and US-UK real exchange rate data from 1974:Q3 to 1992:Q4, and find that monetary shocks are relatively unimportant. They report that monetary shocks account for no more than $50 \%$ of the variance of real exchange rate changes over all time horizons for Germany $(41.1 \%)$, Japan $(35.2 \%)$, the UK $(2.8 \%)$ and Canada (2.5\%). Lastrapes (1992) also uses the Blanchard-Quah approach ${ }^{1}$ to estimate structural VARs and obtains similar results as Clarida and Gali (1994). Eichenbaum and Evans (1995) employ semistructural VARs with three different model specifications and find that the contributions of the monetary shocks are small as well. ${ }^{2}$

Clarida and Gali (1994) speculate that perhaps a different, or larger, information set would imply much greater forecastability of monetary shocks; therefore, the intention of this paper is to re-examine the

*Correspondence to: Shiu-Sheng Chen, Department of Economics, University of Wisconsin-Madison, 1180 Observatory Drive, Madison WI 53706-1393, USA.

${ }^{\dagger}$ E-mail: sschen@ssc.wisc.edu.

Copyright (C) 2003 John Wiley \& Sons, Ltd. 
importance of nominal shocks on real exchange rates using an extended sample period after almost a decade.

In addition, some researchers are sceptical about the Blanchard-Quah type of structural VAR. They argue that the type of long-run restrictions imposed would make sense only if there is a sufficiently long data series. The reason is simple; when we impose that monetary shocks have no effect on the real exchange rate in the long run, it basically means that in our sample the average effect of monetary shocks on the real exchange rate is zero. The real exchange rate, however, converges slowly. ${ }^{3}$

To verify Clarida and Gali's (1994) conjecture and incorporate the critique of the Blanchard-Quah structural VAR, I first extend the data set and update the VAR estimation using quarterly data from 1974:Q3 to 2002:Q4. I then use annual observations from 1889 to 1995 but focus only on the dollar-sterling real exchange rate because of restrictions on data availability. I find that the variance of real exchange rates for Canada, Germany, Japan, and the UK can be attributed more to monetary shocks while the sample is updated to 2002:Q4. Furthermore, monetary shocks can explain nearly 50\% of real US-UK exchange rate variance in the long-run 1889-1995 sample periods. All the evidence suggests that monetary shocks are indeed more important in a larger sample set. A recent paper by Rogers (1999) provides evidence that monetary shocks can account for more variations in real dollar-sterling rate; however, he argues that the choice of model is more important than the sample period. I will compare my results with Rogers' as well.

It is worth noting that the long-run restriction imposed by the Blanchard-Quah approach is not only implied by the Mundell-Fleming-Dornbusch model but also by many other open macro models including simple real business-cycle models. Thus, the employment of structural VARs in this paper is not intended to be an empirical verification of any specific model.

The body of this paper is divided into six parts. Section 2 presents the sources of data. In Section 3, I describe the identification and derivation of the structural VAR model to be employed. The results of estimates are reported in Section 4. Section 5 then lays out the investigations of long-run US-UK data. Following that, a comparison of the results with Rogers' (1999) findings is discussed as well. Finally, concluding remarks are provided in Section 6.

\section{THE DATA}

Quarterly data of the US, Canada, Germany, Japan and the UK from 1974:Q3 to 2002:Q4 are used. Consumer price index $(P)$ is used as the price data. Real GDP $(Y)$ is the GDP volume index and the data for the UK have been adjusted to remove the seasonality. Nominal exchange rates $(E X)$ are foreign currency per US dollar. The real exchange rate $(Q)$ is constructed by $Q=(1 / E R)\left(P^{*} / P^{U S}\right)$, where asterisks denote the foreign countries. All the data are obtained from the IFS data set in Datastream except that the GDP of Japan is obtained from the OECD data set in Datastream. ${ }^{4}$ Names and sources of data are provided in Table 1.

Following standard procedures of recent time-series econometrics, I begin the estimation process by testing the stationarity of the data. I define $y=\left(\ln Y^{U S}-\ln Y^{*}\right), p=\left(\ln C P I^{U S}-\ln C P I^{*}\right)$ and $q=\ln Q$. The results of the Augmented Dickey-Fuller (ADF) test suggest that all series are I(1) series, and hence are stationary in first differences. Guided by this finding, we should test whether $\{y, q, p\}$ is cointegrated over

Table 1. Description of data for baseline model

\begin{tabular}{lll}
\hline Variable & Description & Source \\
\hline$Y$ & Real GDP (Index, 1995 =100) & Datastream \\
$E R$ & Nominal Exchange Rate (to US dollar) & Datastream \\
$C P I$ & Consumer Price Index & Datastream \\
$Q$ & Real Exchange Rate & $Q=\frac{1}{E R} \cdot \frac{C P I^{*}}{C P I}$ \\
\hline
\end{tabular}

Note: All data are quarterly and from 1974:Q3 to 2002:Q4. 
the sample period. I employ Johansen's (1991) maximum likelihood procedure and find that we cannot reject the null of no cointegration among $\{y, q, p\}$ at the $5 \%$ criterion value (1\% for Canada). This suggests that we can estimate the VARs in first differences without imposing any cointegration relationships.

\section{A STRUCTURAL VAR MODEL}

\subsection{Blanchard-Quah identification}

The empirical model contains a three-variable structural VAR $(\Delta y, \Delta q, \Delta p)$ and its identification restriction. The observed variations of economic variables are governed by three mutually orthogonal disturbances: supply shocks, demand shocks and monetary shocks. Formally, we want to transform the reduced form VAR to the structural model:

$$
x_{t}=C(L) \varepsilon_{t}
$$

where

$$
x_{t}=\left[\begin{array}{c}
\Delta y_{t} \\
\Delta q_{t} \\
\Delta p_{t}
\end{array}\right], \quad C(L)=\left[\begin{array}{lll}
C_{11}(L) & C_{12}(L) & C_{13}(L) \\
C_{21}(L) & C_{22}(L) & C_{23}(L) \\
C_{31}(L) & C_{32}(L) & C_{33}(L)
\end{array}\right], \quad \varepsilon_{t}=\left[\begin{array}{c}
\varepsilon_{t}^{s} \\
\varepsilon_{t}^{d} \\
\varepsilon_{t}^{m}
\end{array}\right]
$$

In equation (2), $C_{i j}(L)$ is the polynomial of lag operator $L$, and $\varepsilon_{t}^{s}$, $\varepsilon_{t}^{d}$ and $\varepsilon_{t}^{m}$ are sequences of supply, demand and monetary shocks respectively. The orthogonality assumption implies $E \varepsilon_{t} \varepsilon_{t}^{\prime}=I$. Furthermore, following Clarida and Gali (1994), the restriction that neither monetary shocks $\varepsilon_{t}^{m}$ nor demand shocks $\varepsilon_{t}^{d}$ influence relative output levels in the long run requires that

$$
C_{12}(1)=C_{13}(1)=0
$$

Similarly, the restriction that monetary shocks $\varepsilon_{t}^{m}$ do not influence the real exchange rate in the long run implies that

$$
C_{23}(1)=0
$$

It is worth noting that the Blanchard-Quah identification strategy may have some potential problems. First of all, it may be that monetary shocks do have permanent effects on the real exchange rate. Baldwin (1988), for instance, points out that if market-entry costs are sunk, nominal shocks can alter domestic market structure and thereby influence the real exchange rate in the long run. If this impact is, however, small relative to that of real shocks, the Blanchard-Quah identification is 'nearly correct' as shown in Blanchard and Quah (1989). Therefore, the results of this paper are based on the assumption that they approximately hold. Second, it is likely that there are many other sources for the disturbance affecting the real exchange rates. As Rogers (1999) points out that the effect of multiple aggregation of shocks is empirically important, I will follow Rogers' (1999) identification scheme to check the robustness of my results.

\subsection{Estimation procedure}

I first estimate the baseline VAR model with $x_{t}=\{\Delta y, \Delta q, \Delta p\}$. The estimation proceeds as follows. First, the reduced form VARs are estimated by ordinary least square regression (OLS). To determine the number of lags to include, I apply the Akaike Information Criterion (AIC) to choose the lags of $x_{t}$ for all countries. Second, from the estimated form VARs and long-run restriction denoted in equations (3) and (4), three orthogonal shocks can be disentangled, yielding the estimated coefficients $\left\{C_{i j}: i, j=1,2,3\right\}$ in equation (2). Finally, I will employ variance decompositions, which help us to investigate the sources of real exchange rate fluctuations and, in particular, the roles of monetary shocks. 


\section{EMPIRICAL RESULTS}

\subsection{Variance decomposition}

In order to investigate how much fluctuations in the real exchange rates are due to monetary shocks, I calculate variance decompositions of the real exchange rate $(\Delta q)$ and report the results in Table 2.

In case (A), the sample period is from 1974:Q3 to 1992:Q4, which is exactly the same as Clarida and Gali (1994). It is clear that the results are consistent with Clarida and Gali (1994): (1) we both find that demand shocks are the main source of fluctuations in real exchange rates; (2) monetary shocks account for far less than $50 \%$ of the variance of real exchange rates over all time horizons for each country (Canada: $1.752 \%$, Germany: 27.212\%, Japan: 22.534\%, UK: 0.388\%); (3) monetary shocks explain more of the variance in dollar-DM and dollar-yen real exchange rates than the variance in dollar-sterling and dollar-Canada dollar real exchange rates.

Next, in case (B), the sample span is extended to 2002:Q4. The results are striking: for all countries I examine, the variations of real exchange rates can now be attributed more to monetary shocks. Although it may not seem like a striking improvement in the focastability of monetary shocks, it may imply that a larger sample is helpful to reveal the importance of monetary shocks with the long-run identification scheme.

Imposing a long-run restriction on the VAR model implies that monetary shocks have no effect on real exchange rates in the long run. Since real exchange rates converge slowly, this long-run restriction is reasonable when the sample period is sufficiently long. The empirical evidence reported above motivated me to estimate the structural VARs using the long-run US-UK real exchange rate.

\section{EVIDENCE FROM LONG-RUN US-UK DATA}

The long-run US-UK data used in the baseline model are annual observations from 1889, the earliest availability of the US GNP components, to $1995 .{ }^{5}$ Recently, many studies have started to examine the real exchange rate time series with data over 100 years period. For instance, see Engel and Kim (1999) and Rogers (1999).

Table 2. Variance decomposition $(\Delta q)$

\begin{tabular}{|c|c|c|c|c|}
\hline & & \multicolumn{3}{|c|}{ Canada } \\
\hline & Lags & $\varepsilon^{s}$ & $\varepsilon^{d}$ & $\varepsilon^{m}$ \\
\hline \multirow{4}{*}{$\begin{array}{l}\text { (A) } 74: 3-92: 4 \\
\text { (B) } 74: 3-02: 4\end{array}$} & 1 & $8.75 / 8.56 / 8.56$ & $89.78 / 89.69 / 89.69$ & $1.47 / 1.75 / 1.75$ \\
\hline & 1 & $2.77 / 2.73 / 2.73$ & $92.84 / 92.23 / 92.23$ & $4.39 / 5.03 / 5.03$ \\
\hline & & \multicolumn{3}{|c|}{ Germany } \\
\hline & Lags & $\overline{\varepsilon^{s}}$ & $\varepsilon^{d}$ & $\varepsilon^{m}$ \\
\hline \multirow{4}{*}{$\begin{array}{l}\text { (A) } 74: 3-92: 4 \\
\text { (B) } 74: 3-02: 4\end{array}$} & 3 & $4.39 / 4.76 / 4.88$ & $71.64 / 68.36 / 67.91$ & $23.97 / 26.88 / 27.21$ \\
\hline & 4 & $18.80 / 18.44 / 18.09$ & $40.35 / 41.49 / 40.47$ & $40.85 / 40.07 / 41.44$ \\
\hline & & \multicolumn{3}{|c|}{ Japan } \\
\hline & Lags & $\varepsilon^{s}$ & $\varepsilon^{d}$ & $\varepsilon^{m}$ \\
\hline (A) $74: 3-92: 4$ & 2 & $1.56 / 3.91 / 3.98$ & $78.23 / 73.74 / 73.49$ & $20.22 / 22.35 / 22.53$ \\
\hline \multirow[t]{3}{*}{ (B) $74: 3-02: 4$} & 4 & $9.19 / 9.15 / 9.41$ & $45.47 / 44.69 / 43.67$ & $45.34 / 46.16 / 46.93$ \\
\hline & & \multicolumn{3}{|c|}{ UK } \\
\hline & Lags & $\varepsilon^{s}$ & $\varepsilon^{d}$ & $\varepsilon^{m}$ \\
\hline (A) $74: 3-92: 4$ & 1 & $7.02 / 7.10 / 7.10$ & $92.75 / 92.51 / 92.51$ & $0.23 / 0.39 / 0.39$ \\
\hline (B) $74: 3-02: 4$ & 5 & $7.30 / 8.57 / 8.57$ & $87.88 / 84.24 / 84.02$ & $4.82 / 7.19 / 7.41$ \\
\hline
\end{tabular}

Note: Each cell contains the variance decompositions at horizons 2, 8 and 20 (2/8/20). Lags are chosen by AIC. 
Monthly data on price (PPI), nominal exchange rate and real exchange rate from 1889:M1 to 1995:M2 are exactly the same as that used in Engel and Kim (1999). ${ }^{6}$ I have converted it to annual data simply by averaging. Annual data on output are from the US Bureau of the Census (1975) for the US GNP and Mitchell (1988) for the UK GDP. Updates of the US GNP data are obtained from Table 1.9 of the National Income and Product Accounts Tables, Bureau of Economic Analysis. ${ }^{7}$ The UK GDP data is updated from National Statistics. ${ }^{8}$

I estimate the structural VAR with 17 lags, as suggested by the AIC. Table 3 presents the results for the variance decompositions of long-run US-UK data. The results are quite interesting; the share of variance of real exchange rate changes due to monetary shocks increases substantially. Monetary shocks account for nearly $50 \%$ of exchange rate fluctuations over all time horizons. Further, I employ 16 and 18 lag VARs to test the robustness of this finding and report the results regarding monetary shocks in Table 4 . These estimates corroborate my 17-lag VAR findings. Clarida and Gali (1994) try to explain why the VAR estimates in their model yield the results that monetary shocks explain very little of the variance in real exchange rates. They offer a speculation: perhaps a different, or larger, information set would imply a much greater forecastability. It seems that my results support their conjecture.

The long-run US-UK data span is also examined in Rogers (1999), and he argues that the choice of model is more important than the sample period. Rather than using only three structural shocks: supply shocks, demand shocks and monetary shocks as I employ here, Rogers considers a five-variable VAR with five structural shocks:

$$
x_{t}=C(L) \varepsilon_{t}
$$

where

$$
x_{t}=\left[\begin{array}{c}
\Delta(G / Y) \\
\Delta(y) \\
\Delta(q) \\
\Delta(m m) \\
\Delta(h)
\end{array}\right], \quad C(1)=\left[\begin{array}{ccccc}
C_{11} & 0 & 0 & 0 & 0 \\
C_{21} & C_{22} & 0 & 0 & 0 \\
C_{31} & C_{32} & C_{33} & 0 & 0 \\
C_{41} & C_{42} & C_{43} & C_{44} & 0 \\
C_{51} & C_{52} & C_{53} & C_{54} & C_{55}
\end{array}\right], \quad \varepsilon_{t}=\left[\begin{array}{c}
\varepsilon^{g} \\
\varepsilon^{s} \\
\varepsilon^{D} \\
\varepsilon^{m m} \\
\varepsilon^{h}
\end{array}\right]
$$

Table 3. Variance decompositions $(\Delta q)$

\begin{tabular}{llll}
\hline Horizon & $\varepsilon^{s}$ & $\varepsilon^{d}$ & $\varepsilon^{m}$ \\
\hline 1 & 12.70 & 47.26 & 40.04 \\
2 & 12.85 & 46.53 & 40.63 \\
3 & 12.89 & 42.69 & 44.42 \\
4 & 11.50 & 41.13 & 47.37 \\
8 & 17.85 & 39.06 & 43.10 \\
12 & 18.35 & 33.68 & 47.97 \\
16 & 21.45 & 33.21 & 45.34 \\
20 & 21.98 & 32.56 & 45.46 \\
\hline
\end{tabular}

Note: Long-run US-UK data (1889-1995). Baseline model.

Table 4. Variance decompositions with different lags $(\Delta q)$

\begin{tabular}{ll}
\hline Case & $\varepsilon^{m}$ \\
\hline (1) 16 lags VAR & $34.23 / 34.55 / 37.60 / 40.15 / 38.57 / 43.95 / 42.42 / 43.55$ \\
(2) 18 lags VAR & $42.36 / 42.65 / 43.45 / 48.85 / 42.75 / 45.62 / 42.87 / 40.62$ \\
\hline
\end{tabular}

Note: Each cell contains the variance decompositions at horizons 1-4, 8, 12, 16 and 20 (1/2/3/4/8/12/16/ $20)$. Only the variance due to monetary shock $\left(\varepsilon^{m}\right)$ is reported and compared. Long-run US-UK data (1889-1995). 
where, $(G / Y)$ is the real government consumption relative to real output, $(y)$ is the log of real output, $(q)$ is the log of real exchange rate, $(\mathrm{mm})$ is the log of monetary multiplier and $(h)$ is the log of real money base. All variables are UK relative to US. The structural shocks are identified as fiscal shocks $\left(\varepsilon^{g}\right)$, productivity shocks $\left(\varepsilon^{s}\right)$, preference shocks $\left(\varepsilon^{D}\right)$, money multiplier shocks $\left(\varepsilon^{m m}\right)$ and monetary base shocks $\left(\varepsilon^{h}\right)$.

The historical data on prices and output for the US in Rogers (1999) are from Kendrick (1961). His data on prices and output for the UK and nominal exchange rates are from Mitchell (1988). Figure 1 plots the real exchange rate and real output data used in both Rogers (1999) and this paper. ${ }^{9}$

In order to compare the results of baseline long-run US-UK data with Rogers' (1999) findings, I will consider the following experiments. Case 1: estimating the baseline model with Clarida and Gali's (1994) sample span, 1974 to 1992. Case 2: replacing the real output data with Rogers' output data in the baseline model. Case 3: the same as case 2 except that the sample span is 1974 to 1992. Case 4: using my real exchange rate (Engel and Kim's (1999) PPI-based real exchange rate) with Rogers' other four variables to estimate the five-variable VAR model described in equations (5) and (6) for his full long-run sample period (1889-1992). Case 5: replacing the three-variable VAR $(\Delta y, \Delta q, \Delta p)$ with $(\Delta y, \Delta q, \Delta m), m=\log (M / H)$, US less UK, where $M$ is the nominal M2 monetary shock (mid-year observation) and $H$ is the nominal monetary base (mid-year observation). ${ }^{10}$ Case 6: the same as case 5 except that the sample span is 1974 to 1992.

All the results are reported in Table 5. The estimates from the baseline model (case 0 ) are presented in the first line of the table. Investigating case 1 and case 0 , it is clear that a longer sample period does increase the percentage of variance in real exchange rates that monetary shocks can account for. Cases 2 and 3 indicate that using an alternative real output data does not alter the conclusion: the long time period does change the results. In case 4, the percentage of monetary shocks reported here is the combination of the money multiplier shocks and the monetary base shocks $\left(\varepsilon^{m m}+\varepsilon^{h}\right)$. It is clear that the identification scheme considered in Rogers (1999) does not reveal the importance of nominal shocks well when my real exchange rate data is used. In case 5, using monetary variable $(\Delta m)$ rather than simply an inflation variable $(\Delta p)$ provides a robustness check of the results in the baseline model: monetary shocks still play a more important role in accounting for the variations of dollar-sterling real exchange rates than initially found in Clarida and Gali (1994). Finally, comparing case 5 with case 6, it may suggest that a longer sample period is helpful in terms of identifying the importance of monetary shocks.

All the experiments employed here may have an interesting implication: the conclusion that the choice of model is more important than the sample period does not necessarily hold when alternative data is used. The purpose of these experiments is not to claim that Engel and Kim's (1999) data is preferred over Rogers'
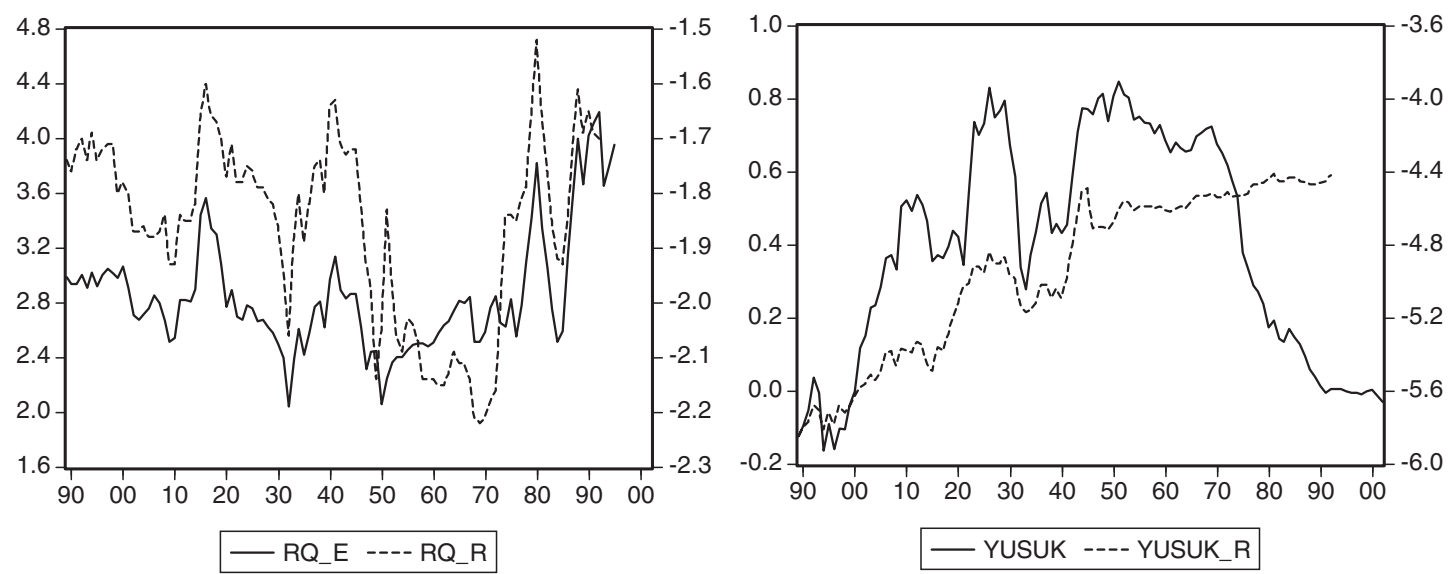

Figure 1. Real exchange rate and real output. $R Q_{E}$ : Engel and Kim's (1999) real exchange rate. $R Q_{R}$ : Rogers' (1999) real exchange rate. YUSUK: my real output data (US-UK). YUSUK ${ }_{R}$ : Rogers' (1999) real output data (US-UK). 
Table 5. Variance decompositions in alternative models $(\Delta q)$

\begin{tabular}{lcc}
\hline Case & Lags & $\varepsilon^{m}$ \\
\hline 0 & 17 & $40.63 / 47.37 / 43.10 / 45.34 / 45.46$ \\
1 & 1 & $12.41 / 16.11 / 16.12 / 16.12 / 16.12$ \\
2 & 20 & $14.34 / 19.64 / 21.88 / 25.19 / 25.57$ \\
3 & 1 & $0.39 / 0.46 / 0.48 / 0.48 / 0.48$ \\
4 & 1 & $6.42 / 6.46 / 6.46 / 6.46 / 6.46$ \\
5 & 20 & $21.09 / 17.94 / 19.58 / 26.73 / 30.51$ \\
6 & 1 & $11.87 / 11.48 / 11.48 / 11.48 / 11.48$ \\
\hline
\end{tabular}

Note: Each cell contains the variance decompositions at horizons 2, 4, 8, 12,16 and 20 (2/4/8/16/20). Only the variance due to monetary shock $\left(\varepsilon^{m}\right)$ is reported and compared. Case 0 is the baseline model. Case 1 is the baseline model with sample period 1974-1992. Case 2 replaces real output with Rogers' (1999) data. Case 3 is the same as case 2 but with sample period 1974-1992. Case 4 is the five-variable VAR model in Rogers (1999) with Rogers' data except that the real exchange rate is replaced by Engel and Kim's (1999) data. Case 5 is the same as the baseline model except that $\Delta p$ is replaced by $\Delta m$. Case 6 is the same as case 5 except that the sample span is 1974-1992. Lags are chosen by AIC.

(1999) data, but to prove the robustness of my empirical results and re-examine the claims in Rogers (1999) when a different data set is used.

\section{CONCLUDING REMARKS}

Evidence presented in this paper suggests that monetary shocks are more important in a larger sample set, as Clarida and Gali (1994) speculate. The paper's methodology is straightforward. I first estimate Clarida and Gali's (1994) VAR model with updated sample observations and the obtained results suggest that the variance of real exchange rates can be attributed more to monetary shocks when the sample span is extended. I then employ a VAR model with long-run US-UK annual data from 1889 to 1995 . According to the variance decompositions, I find that more of the real exchange rate variance can be explained by monetary shocks in the long-run sample periods (near 50\%) than in initial findings. This verifies Clarida and Gali's (1994) conjecture. Furthermore, my results using the long-run US-UK data may provide a credible response to the criticism that the Blanchard-Quah restriction makes sense only when examining a longer sample period.

\section{ACKNOWLEDGEMENTS}

I would like to thank Charles Engel for his useful comments. It is greatly appreciated that John Rogers kindly provided his data for comparison purposes. Any remaining errors are my own responsibility.

\section{NOTES}

1. Clarida and Gali (1994) identify three shocks: supply shocks, demand shocks and monetary shocks, whereas Lastrapes (1992) only identifies two shocks, a real shock and a nominal shock.

2. The mean contributions of the monetary policy shock across the three specifications are $19.3 \%, 27.48 \%, 25.68 \%, 23.54 \%$ and $17.93 \%$ for Japan, Germany, Italy, France and the UK respectively.

3. I would like to thank Charles Engel for clarifying this point.

4. The GDP of Japan in the IFS data set contains seasonality before 1980.

5. The reason I focus on UK only is due to data availability.

6. The data is available on Charles Engel's website: http://www.ssc.wise.edu/ cengel/data.htm

7. See http://www.bea.doc.gov/bea/dnl.htm

8. See http://www.statistics.gov.uk 
9. I would like to thank John Rogers for kindly providing me the data set. Note that in Rogers' data set, all variables are in UK-US difference, and the real exchange rate is constructed as $(£ / \mathrm{US} \$) \times\left(P^{U K} / P^{U S}\right)$. I have reversed all his data to match my setting as US-UK difference and real exchange rate: $(\mathrm{US} \$ / £)\left(P^{U S} / P^{U K}\right)$.

10. The data is the same as in Rogers (1999) and kindly provided by Rogers.

\section{REFERENCES}

Baldwin, R. 1988. Hypothesis in import prices: the beachhead effect. American Economic Review 78: 773-785.

Beaudry P, Devereux M. 1995. Money and the real exchange rate with sticky prices and increasing returns. Carnegie-Rochester Conference Series on Public Policy 43: 55-102.

Bureau of the Census, United States. 1975. Historical Statistics of the United States: Colonial Times to 1970. US Department of Commerce.

Blanchard O, Quah D. 1989. The dynamic effects of aggregate demand and supply disturbances. American Economic Review 79(4); $655-673$.

Chari V, Kehoe P, McGrattan E. 2000. Can sticky price models generate volatile and persistent real exchange rates? Federal Reserve Bank of Minneapolis Research Department Staff Report 277.

Clarida R, Gali J. 1994. Sources of real exchange-rate fluctuations: how important are nominal shocks. Carnegie-Rochester Conference Series on Public Policy 41: 1-56.

Eichenbaum, M, Evans CL. 1995. Some empirical evidence on the effects of shocks to monetary policy on exchange rates. Quarterly Journal of Economics 110: 975-1010.

Engel C, Kim, C-J. 1994. The long-run US-UK real exchange rate. Journal of Money, Credit, and Banking 31(3): 335-356.

Johansen S. 1991. Estimation and hypothesis testing of cointegration vectors in Gaussian vector autoregressive models. Econometrica 59: $1551-1580$

Kendrick J. 1961. Productivity Trends in the United States. General Series, no. 71. Princeton University Press: Princeton, NJ.

Lastrapes W. 1992. Sources of fluctuationsin real, nominal exchange rates. Review of Economics and Statistics 74(3): 530-539.

Mitchell B. 1988. British Historical Statistics. Cambridge University Press: Cambridge.

Mussa M. 1986. Nominal exchange rate regimes, the behavior of real exchange rate: evidence and implications. Carnegie-Rochester Conference Series on Public Policy 25: 117-214.

Obstfeld M, Rogoff K. 1995. Exchange rate dynamics redux. Journal of Political Economics 102: 624-660.

Rogers J. 1999. Monetary shocks and real exchange rates. Journal of International Economics 49: 269-288. 